\title{
Stygobromus bakeri, a new species of groundwater amphipod (Amphipoda, Crangonyctidae) associated with the Trinity and Edwards aquifers of central Texas, USA
}

\author{
Randy Gibson', Benjamin T. Hutchins ${ }^{2}$, Jean K. Krejca ${ }^{3}$, \\ Peter H. Diaz ${ }^{4}$, Peter S. Sprouse ${ }^{3}$
}

I San Marcos Aquatic Resources Center, United States Fish and Wildlife Service, 500 East McCarty Lane, San Marcos, Texas, 78666, USA 2 Edwards Aquifer Research and Data Center, Texas State University, 220 East Sessom Drive, San Marcos, Texas, 78666, USA 3 Zara Environmental LLC., 1707 West FM 1626, Manchaca, TX. 78652, USA 4 Texas Fish and Wildlife Conservation Office, United States Fish and Wildlife Service, 500 East McCarty Lane, San Marcos, Texas, 78666, USA

Corresponding author: Randy Gibson (randy_gibson@fws.gov)

Academic editor: Thomas Sawicki | Received 8 December 2020 | Accepted 2 March 2021 | Published 12 April 2021

http://zoobank.org/695318A5-5399-48D9-BC92-9C846F7D397E

Citation: Gibson R, Hutchins BT, Krejca JK, Diaz PH, Sprouse PS (2021) Stygobromus bakeri, a new species of groundwater amphipod (Amphipoda, Crangonyctidae) associated with the Trinity and Edwards aquifers of central Texas, USA. Subterranean Biology 38: 19-45. https://doi.org/10.3897/subtbiol.38.61787

\begin{abstract}
A new stygobitic groundwater amphipod species, Stygobromus bakeri sp. nov., is described from 4 central Texas limestone karst springs; John Knox Spring (Comal County), Jacob’s Well (Hays County), Mormon Spring (Travis County) and Salado Springs (Bell County). This species belongs to the predominately western Nearctic hubbsi species group of Stygobromus and differs from other species in the group by gnathopod 1 with row of 4 to 5 setae posterior to the defining angle, pereopods 6 and 7 with broadly expanded bases and distinct distoposterior lobes, gnathopods 1 and 2 with 2 rows of 3 singly inserted setae on the inner palm, and uropod 3 with single, slightly distal peduncular seta. Habitat, sympatric groundwater species, and conservation issues are discussed.
\end{abstract}

\section{Keywords}

cave, crenobiont, interstitial crustacean, karst, spring, stygobiont, stygobite, subterranean, sympatric, troglomorphy

Copyright Randy Gibson et al. This is an open access article distributed under the terms of the Creative Commons Attribution License (CC BY 4.0), which permits unrestricted use, distribution, and reproduction in any medium, provided the original author and source are credited. 


\section{Introduction}

The Nearctic amphipod genus Stygobromus Cope, 1872 (Amphipoda, Crangonyctidae) currently includes 137 described species and 4 subspecies in the United States and Canada (Hay 1882; Hubricht 1943; Derzhavin 1945; Holsinger 1967; Holsinger 1969; Holsinger 1974; Holsinger 1978; Wang and Holsinger 2001; Holsinger 2009; Sidorov et al. 2010; Holsinger et al. 2011; Taylor and Holsinger 2011; Holsinger and Ansell 2014; Holsinger and Sawicki 2016; Cannizzaro et al. 2019; Palatov and Marin 2020). The genus is entirely stygomorphic, and, as with most groundwater-obligate taxa, low detection probability (a function of inaccessible habitat and low population densities), coupled with pervasive convergent evolution (Eberhard et al. 2009; Culver and Pipan 2015; Devitt 2019) results in an incomplete understanding of diversity and systematics within the genus. Many species, cryptic and otherwise, await description. Holsinger (1974) and Wang and Holsinger (2001) provisionally assigned 45 of 54 currently recognized taxa in the western United States and southwestern Canada to the hubbsi group. Although molecular data supporting systematic relationships are lacking for most taxa (but see Ethridge et al. 2013; Aunins et al. 2016; Cannizzaro et al. 2019), the hubbsi group is supported morphologically by lack of sternal gills on the pereonites and a combination of additional characters summarized by Wang and Holsinger (2001). The distribution of Stygobromus in Texas is mapped in Figure 1. In the Edwards Plateau and Balcones Escarpment of central Texas, USA, 9 Stygobromus species are documented alongside diverse assemblages of stygobiontic crustaceans (Holsinger 1967; Gibson et al. 2008; Hutchins 2018; Nissen et al. 2018). Four central Texas Stygobromus species belong to the tenuis group: S. balconis (Hulbricht, 1943), S. reddelli (Holsinger, 1966), S. russelli (Holsinger, 1967), and S. bifurcatus (Holsinger, 1967). Four comprise the central Texas endemic flagellatus group: S. flagellatus (Benedict, 1896), S. longipes (Holsinger, 1966), S. dejectus (Holsinger, 1967), and S. pecki (Holsinger, 1967). Stygobromus hadenoecus (Holsinger, 1966) is the sole described member of the hadenoecus group found in the western Edwards Plateau. The nearest hubbsi group species, S. limbus Wang \& Holsinger, 2001, occurs more than $300 \mathrm{~km}$ away from the Edwards Plateau taxa in a southeastern extension of the Basin and Range Province of the western United States in far west Texas. Huston and Gibson (2018) reported an undescribed species in the hubbsi group from a single spring site in the Chisos Basin of Big Bend National Park, Texas, also within the Basin and Range Province. Only a single hubbsi group species, S. putealis (Holmes, 1909) from wells in Wisconsin, is currently known from east of North America’s western Cordillera (Wang and Holsinger 2001).

Stygobromus species of the hubbsi group are recorded in a variety of groundwater habitats including caves, wells, the hyporheic zone of surface streams, karstic and nonkarstic springs, and hypotelminorheic seeps. Two species live in the depths (5-495 m) of Lake Tahoe (California and Nevada) although Wang and Holsinger (2001) hypothesized that their preferred habitat may actually be adjacent groundwater.

Many groundwater habitats and groundwater-obligate organisms are at risk from a myriad of threats, including groundwater contamination, physical habitat destruction 


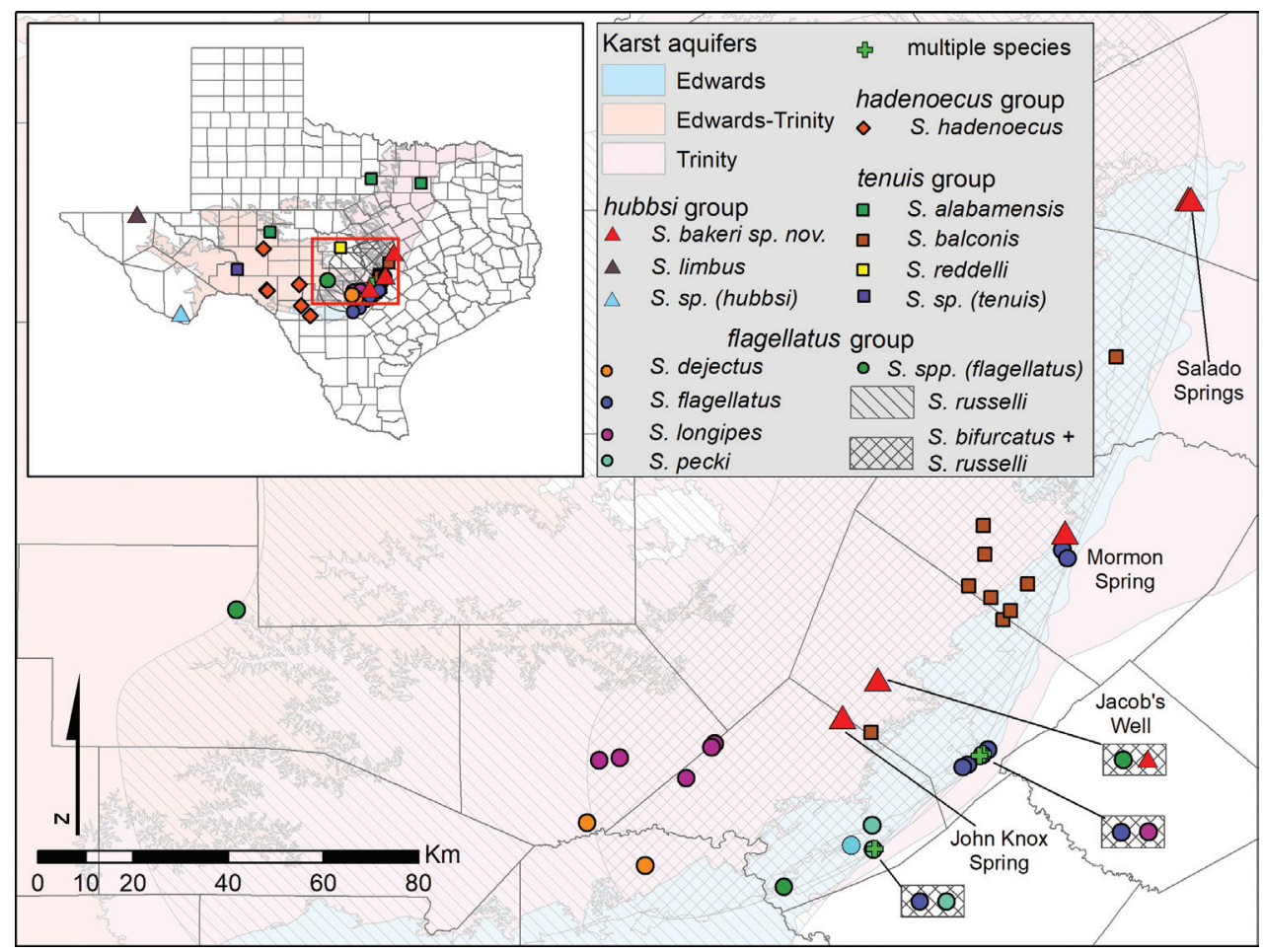

Figure I. Stygobromus distribution in Texas. Red square expanded to view central Texas species. Individual undescribed species represented by $S$. sp. and $S$. spp. (flagellatus) refers to several undescribed site endemic species in the flagellatus group (Hutchins 2018).

(e.g. gravel mining), and groundwater extraction (Burri et al. 2019; de Graaf et al. 2019), lending urgency to continued documentation of groundwater biodiversity. Here, we describe the $12^{\text {th }}$ species of Stygobromus from Texas, USA and the first species belonging to the hubbsi group in the Edwards Plateau/Balcones Escarpment region, an area where groundwater extraction to meet the demand of a rapidly growing human population along the Interstate 35 highway corridor increasingly threatens groundwater resources.

\section{Materials and methods}

Specimens were collected from karst springs using 150-250 $\mu \mathrm{m}$ mesh drift nets and using multiple techniques at an underwater cave, Jacob's Well (Fig. 2A) accessed via the resurgence entrance using SCUBA (Fig. 2B, C). Divers performed surveys at Jacob's Well, Hays County on 20 occasions from May 2009 to June 2011, using visual searches, a drift net placed at a vertical constriction at $-25 \mathrm{~m}$ depth and $42 \mathrm{~m}$ penetration, cloth lures secured to the side of the cave shaft near the entrance, and baited bot- 


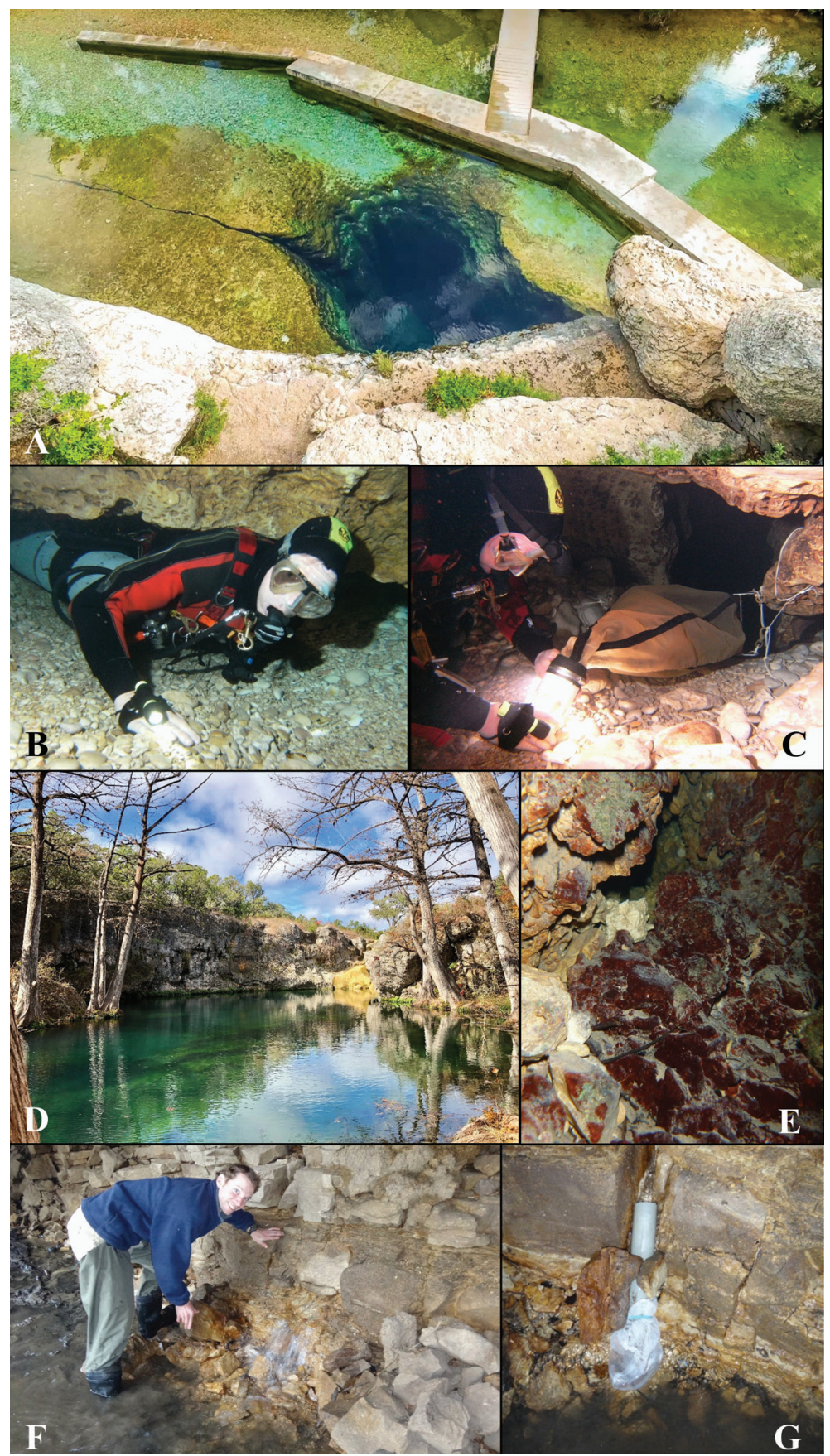

Figure 2. Comal, Hays, and Travis counties, Texas spring sites for Stygobromus bakeri sp. nov. Jacob's Well A cave entrance B second constriction point (30 m water depth), Stygobromus bakeri sp. nov. were found deeper than this point $\mathbf{C}$ drift net at first constriction point ( $23 \mathrm{~m}$ water depth). John Knox Ranch D Blue Hole, perennial headwaters of Carper's Creek E John Knox Spring issuing within Blue Hole. Mormon Spring \#3 F Spring exposed under boat dock during drought $\mathbf{G}$ drift net on spring site. Photograph credit: Jean Krejca (A-C); courtesy of John Knox Ranch (D); Randy Gibson (E); Peter Sprouse (F, G). 


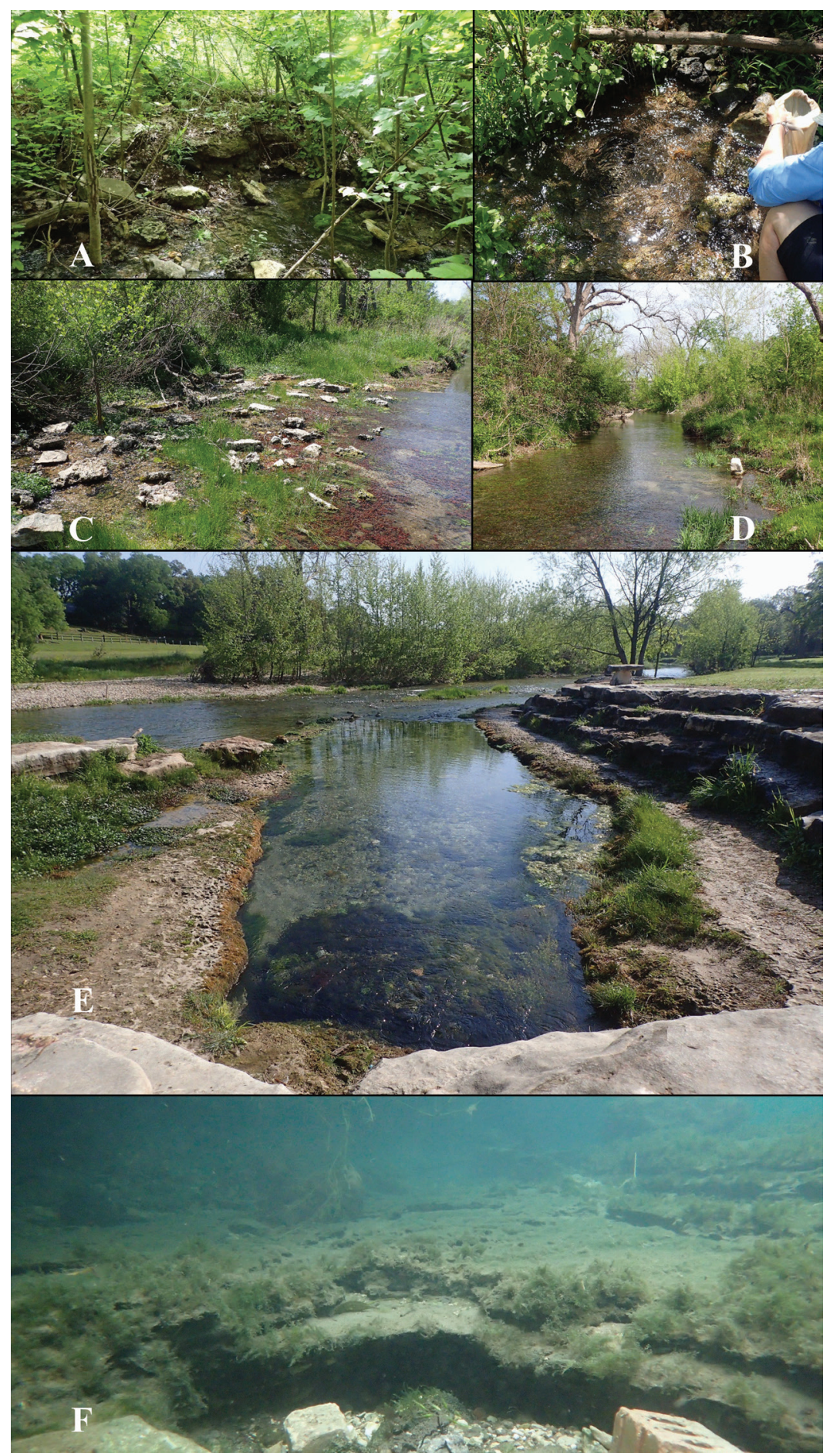

Figure 3. Salado, Bell County, Texas spring sites for Stygobromus bakeri sp. nov. Robertson Spring Complex A Beetle Spring B Middle Spring C Ludwigia Spring D Creek Spring upwelling below water surface. Downtown Spring Complex E Big Boiling Spring F Anderson Spring. Photographs by Pete Diaz. 
tle traps placed in a broad, low room at $-30 \mathrm{~m}$ depth and $70 \mathrm{~m}$ penetration. The visual search area within the underwater passage began at the shaft below the spring opening and up to a maximum penetration of $330 \mathrm{~m}$. Hand sampling was performed using basters, fine aquarium dipnets, and centrifuge vials. Külköylüoğlu and Gibson (2018) and Külköylüoğlu et al. (2017) described collection details at John Knox Springs, Comal County. Surveys using $250 \mu \mathrm{m}$ drift nets at springs in the city of Salado, Bell County (Fig. 3) began in 2015 and have continued seasonally as part of a monitoring project for the endangered Salado salamander, Eurycea chisholmensis Chippindale, Price, Wiens \& Hillis, 2000 at 10 spring orifices at Robertson Springs and 2 spring orifices at the Downtown Spring Complex (Diaz and Warren 2019). Mormon Spring \#3, in Travis County was sampled using $150 \mu \mathrm{m}$ drift nets from 20 January to 23 February 2017 . All samples were stored in $95 \%$ ethanol.

Specimens were dissected, and mouthparts and appendages were mounted in glycerin. Images and measurements were acquired at multiple magnifications and focal points using an Olympus BX-45 compound stereomicroscope and Nikon DS-5M digital camera. Images were imported into Abode Illustrator Creative Suite 5 software and line drawing illustrations were produced using a Wacom Cintiq 22HD Interactive Pen Display. Nomenclature for setal arrangement on the mandibular palps follows Cole (1980) for segment 2 and Stock (1974) for segment 3. The "defining angle" of the gnathopod propodus is the area where the tip of the dactylus rests on the posterior margin of the palm. "Robust setae" and "setae" were used in place of the traditional "spine teeth" and "spines" following Watling (1989) and Cannizzaro et al. (2019).

\section{Results}

Systematics

Class Crustacea Brünnich, 1772

Order Amphipoda Latreille, 1816

Suborder Senticaudata Lowery \& Myers, 2013

Infraorder Gammarida Latreille, 1802

Parvorder Crangonyctidira Bousfield, 1973

Superfamily Crangonyctoidea Bousfield, 1973

Family Crangonyctidae Bousfield, 1963; emended by Holsinger 1977

Genus Stygobromus Cope, 1872

Stygobromus bakeri Gibson \& Hutchins, sp. nov.

http://zoobank.org/AF7212A6-35E0-481C-ADCC-29A809611191

Fig. 4

Type locality. USA, Texas, Comal County, John Knox Ranch, John Knox Spring (29.9642, -98.1956). 


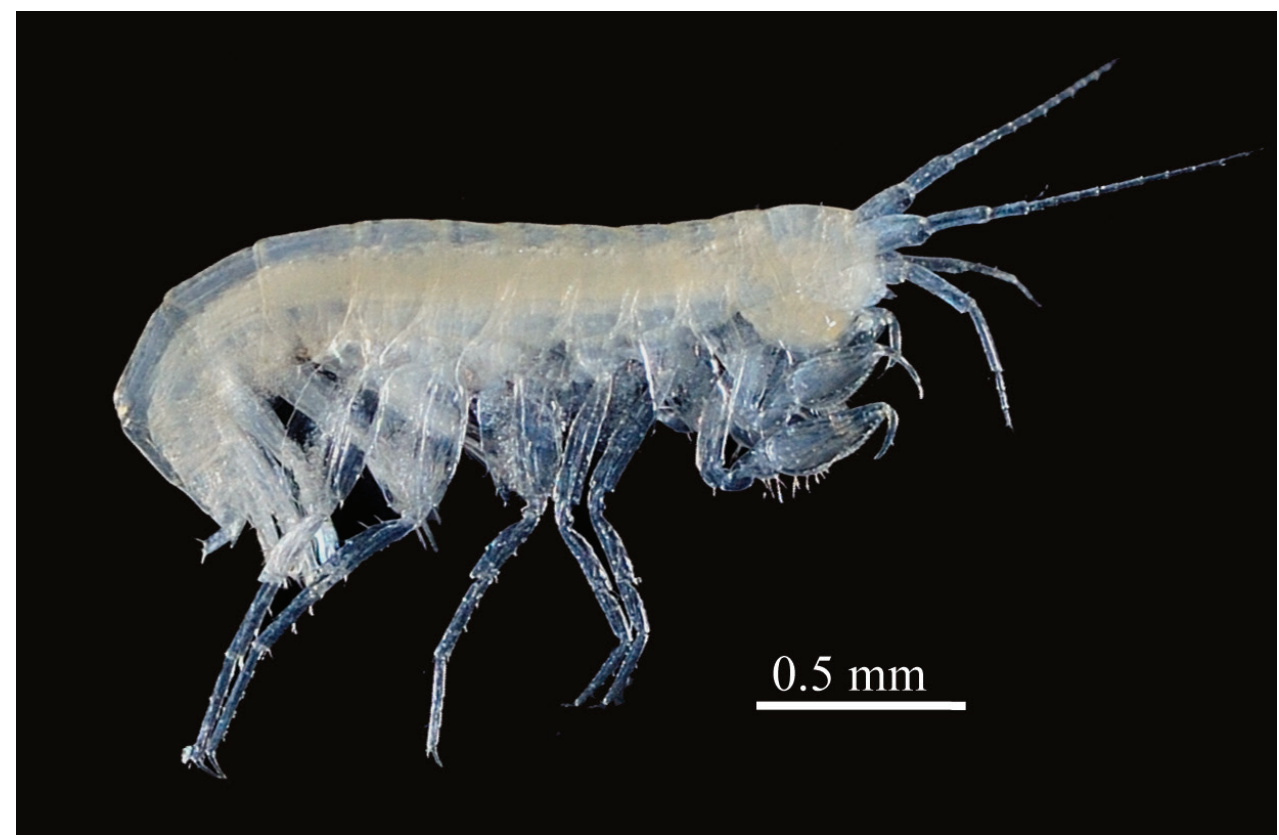

Figure 4. Stygobromus bakeri sp. nov. collected live from Jacob’s Well. Photograph by Jean Krejca.

Material examined. All sites are in Texas, USA. Holotype female (4.6 mm) Comal County, John Knox Ranch, John Knox Spring: collected by Randy Gibson (RG), 6 May 2010, dissected slide mounts Texas State University Aquifer Biodiversity Collection. Allotype male $(3.1 \mathrm{~mm})$ - Comal County, John Knox Ranch, John Knox Spring: collected by RG, 16 April 2010. Paratypes - John Knox Spring: juvenile $(1.7 \mathrm{~mm}$ ) collected by RG, 6 January 2010; 2 males $(3.5$ and $3.6 \mathrm{~mm}$ ) and juvenile (2.4 mm) collected by RG, 6 April 2010; 2 males $(2.5$ and $3.4 \mathrm{~mm}$ ) collected by RG, 2 May 2010; juvenile (2.4 mm) collected by RG, 6 May 2010; damaged female (4.5 mm) collected by RG, 10 May 2010; 2 males $(3.1 \mathrm{~mm}$ and $4.1 \mathrm{~mm}$ ) collected by RG, 13 May 2010; male $(3.5 \mathrm{~mm})$ and juvenile $(2.3 \mathrm{~mm})$ collected by $\mathrm{RG}, 21$ May 2010. - Hays County, Jacob's Well (30.0345, -98.1261): male (4.2 mm) collected by Jean Krejca (JK), 21 October 2009; female $(4.5 \mathrm{~mm})$ collected by JK, 6 May 2010; female $(3.5 \mathrm{~mm})$ collected $(\approx 43 \mathrm{~m}$ depth) by JK and James Brown, 4 August 2010; brooding female $(4.4 \mathrm{~mm})$, male $(4.1 \mathrm{~mm})$ and 2 juveniles collected by JK 31 May 2011; 2 males (4.4 and $2.9 \mathrm{~mm})$ collected by JK, 16 June 2013; male $(3.2 \mathrm{~mm})$ collected by Matt Turner, 8 September 2013.

Additional material examined. - Travis County, Mormon Spring no. 3 (30.3132, -97.7747): 1 damaged female $(4.4 \mathrm{~mm})$ collected by P. Sprouse, 30 January 2017 (Zara \# 9450, TMM \# 91,955). - Bell County, Middle Robertson Spring (Robertson Springs Complex) (30.9444, -97.5410): female (4.2 mm) collected by Andy Gluesenkamp, 12 Dec 2009; juvenile $(1.7 \mathrm{~mm})$ collected by RG and Pete Diaz (PD), 30 July 2015; male (2.7 mm) collected by PD, 26 April 2017. Sam Bass Spring 
(Robertson Springs Complex) (30.9444, -97.5410): male $(4.5 \mathrm{~mm})$ collected (drift net) by PD and RG, 1 Mar 2016. Upper Ludwigia Spring (Robertson Springs Complex) $(30.9444,-97.5411)$ : male $(3.1 \mathrm{~mm})$, collected (drift net) by PD, 20 January - 6 June 2017. Creek Spring (Robertson Springs Complex) (30.9445, -97.5414): male $(3.0 \mathrm{~mm})$ collected by PD, 12 April 2018; 2 males (4.1 and $3.2 \mathrm{~mm}$ ) collected by PD, 27 November 2018. Big Boiling Spring (Downtown Springs Complex) (30.9437, -97.5366): male $(3.2 \mathrm{~mm})$ collected by RG and PD, 25 September 2015. Anderson Spring (Downtown Springs Complex (30.9441, -97.5346): damaged specimen $(2.9 \mathrm{~mm})$ collected (drift net) by PD, 1 November 2016-20 January 2017. Whole paratypes are deposited in the National Museum of Natural History, Smithsonian Institution (USNM accession \# 1638682-1638690) and Texas State University Aquifer Biodiversity Collection (ABC accession \# 0021059-002171).

Diagnosis. Small stygobitic species similar to most members of the hubbsi group with mature females larger than males, gnathopod 2 larger than gnathopod 1, posterior margin of gnathopod 1 typically shorter than palm, and telson as long as broad with shallow notch in apical margin. Distinguished from other hubbsi group species by gnathopods 1 and 2 with 2 rows of 3 singly inserted setae on the inner palm, and combination of following characters: gnathopod 1 with row of 4 to 5 setae posterior to the defining angle (compare to $S$. quatsinensis Holsinger \& Shaw, 1986 with 2 or 3 postmarginal setae, 3 hubbsi group species have 1 or 2 postmarginal setae and all others are lacking); pereopods 6 and 7 with broadly expanded bases and distinct distoposterior lobes (similar to S. salturus Wang \& Holsinger, 2001); and uropod 3 with single, slightly distal peduncular seta (similar to S. lanensis Wang \& Holsinger, 2001).

Description. Female (4.6 mm). Antenna 1 (Fig. 5, A1): 39\% length of body, ca. $1.7 \times$ longer than antenna 2; primary flagellum with 10 segments, aesthetacs on segment 3-10; accessory flagellum 2 segmented reaching up to flagellar segment 2. Antenna 2 (Fig. 5, A2): flagellum with 3 segments. Mandibles (Fig. 5, 1Mdb, rMdb): left mandible incisor 5-dentate, lacinia mobilis 5-dentate, with 5 robust, plumose accessory setae, molar protruding and non-triturative with tuft of setae on anterior margin, blade-like teeth and single long rastellate seta. Right mandible incisor 5-dentate, lacinia mobilis 3-dentate, 1 serrate, 1 forked apically, and last with row of denticles and long setae at base; accessory setae row with 2 robust serrate setae and tufts of long setae basally; molar and palp similar to left mandible. Palp 3-segmented, segment 2 and 3 subequal; segment 2 with 2 alpha and 1 beta setae, fringe of small hair-like setae lining inner margin and fringe of pubescence lining outer distal margin; segment 3 with $1 \mathrm{~B}$ seta, $5 \mathrm{E}$ setae, $6 \mathrm{C}$ setae, small hair-like $\mathrm{D}$ setae, A setae absent, and fringe of pubescence lining outer distal margin. Lower lip (Fig. 5, Li): covered in fine hairs with inner lobes poorly developed. Maxilla 1(Fig. 5, Mx1) inner plate with 4 plumose setae; outer plate with 7 comb-spines ( 1 with inner medial margin lined with setae, 2 serrate, and 4 gaffate); palp 2-segmented, with 3-4 setae ( 2 apical, 1-2 subapical) and ca. 10 small hair like setae. Maxilla 2 (Fig. 5, Mx2) inner plate with 13 setae, 7 longer plumose setae along inner margin and 6 shorter apical setae; outer plate with 9 setae 


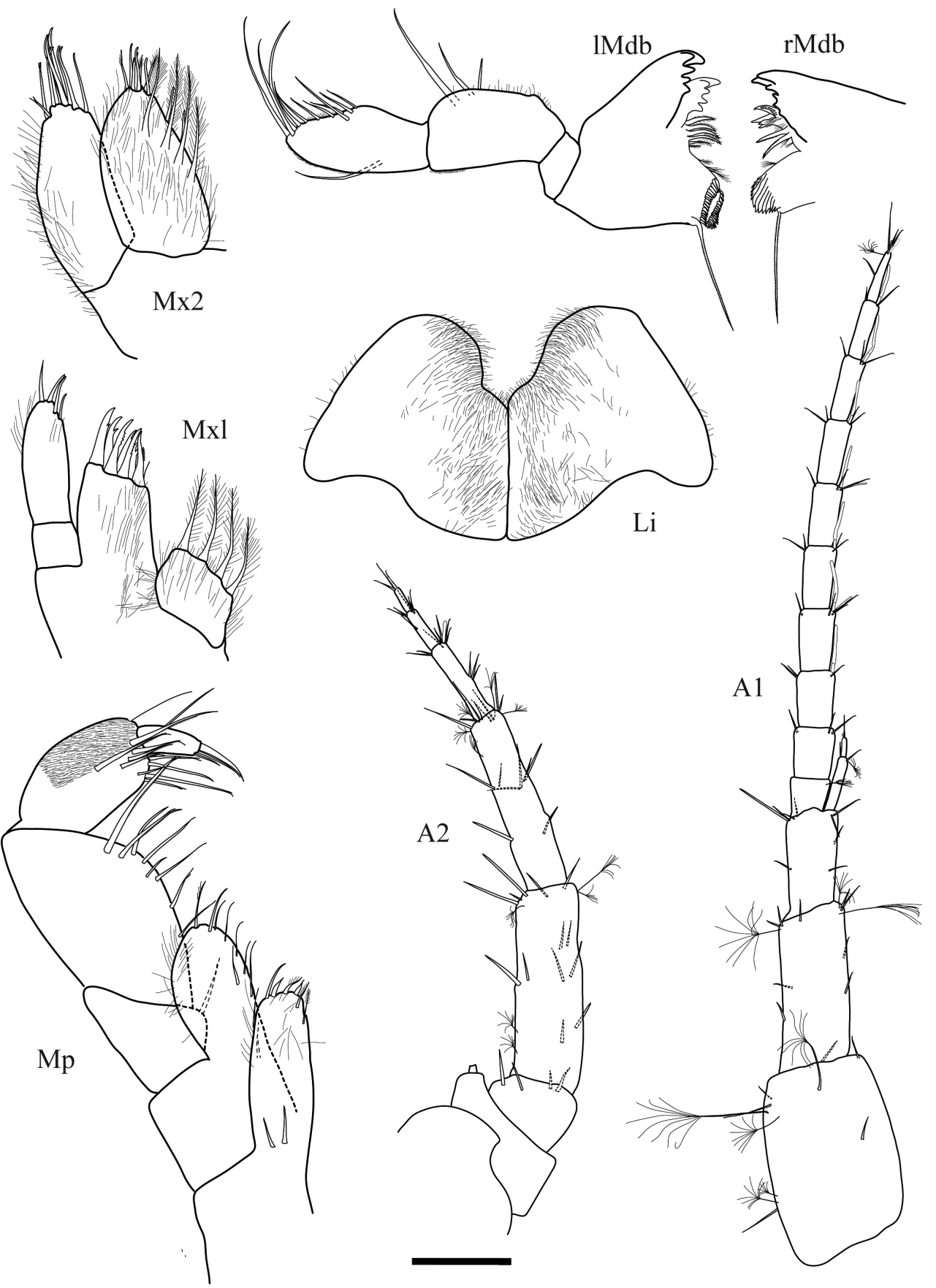

Figure 5. Stygobromus bakeri sp. nov., Holotype $q$ ( $4.6 \mathrm{~mm})$, John Knox Spring, Comal Co., Texas AI antenna 1 A2 antenna 2 Li lower lip Mp maxilliped $\mathbf{M x I}$ maxilla $1 \mathbf{M x 2}$ maxilla 2. Paratype $\widehat{\sigma}$ (3.1 mm), John Knox Spring, Comal Co., TX. IMdb left mandible and mandibular palp rMdb right mandible. Scale bars: 0.05 mm (Li, Mp, MxI, Mx2, IMdb, rMdb); 0.1 mm (AI,A2). 
(mostly finely serrate, and 1 with apical minute setule) and an additional shorter seta on outer margin. Maxilliped (Fig. 5, Mp) inner plate with 3 apical spine-teeth, 2 plumose submarginal setae, and 2 longer setae arising at base; outer plate with 8-9 long simple setae and 1 outer apical seta with apical marginal setules; palp 4 segmented, second segment about $2 \times$ longer and wider than third, segment 1 with seta on inner margin, segment 2 with 6-8 setae on inner margin, 2 of these finely serrate, apical seta longer than rest, segment 3 with 8-11 setae, a few finely serrate and many forked apically, a densely pubescent patch located on dorsal face from midline to outer margin of segment, segment 4 with 2 setae apically at base of nail, one seta on outer margin medially, nail subequal in length to segment 4.

Gnathopod 1 (Fig. 6, G1): propodus shorter than that of gnathopod 2; coxal plate longer than broad, with 1 ventral and 2 anterior marginal setae; basis with 5 long setae inserted along posterior margin; ischium with 2 setae and scale patch along posterior margin; merus with 9 posterodistal setae and patch of pubescence; carpus 36\% length of propodus, with 9 setae; propodus $1.5 \times$ longer than widest point with 3 superior and 3 inferior medial setae, palm slightly convex with 10 inner and 11 outer bifurcate robust setae, 2 of these posterior to defining angle, defining angle rounded and sub angular, margin posterior to defining angle ca. half the length of the palm with 4-5 setae and scaly patch becoming finer at defining angle and granular along inner margin of dactylus depression; dactylus with 1 seta on outer margin and 3 on distal half of inner margin; dactylus nail ca. 21\% length of dactylus.

Gnathopod 2 (Fig. 6, G2): propodus 1.3× longer than that of gnathopod 1; coxal plate quadrate, with 1 ventral and 2 anterior marginal setae; basis with 1 long seta on anterior margin, shorter seta on posterodistal margin; ischium with 1 seta and scale patch on posterior surface; merus with 2 posterodistal setae, scale patch on posterior surface; carpus $25 \%$ length of propodus, with 3 distal setae, 7 setae and scale patch on posterior surface; propodus ca. $2 \times$ longer than widest point with 3 superior and 3 inferior medial setae, palm straight to slightly convex with 11 inner and 13 outer bifurcate robust setae, 2 of these posterior to defining angle and 3 sets of paired setae, 2 of these posterior to defining angle, defining angle rounded, margin posterior to defining angle ca. half the length of the palm with scaly patch on poster margin becoming finer at defining angle and granular along inner margin of dactylus depression; dactylus with 1 seta on outer margin; dactylus nail ca. $15 \%$ length of dactylus.

Pereopod 3 (Fig. 7, P3): subequal in length to pereopod 4; coxal plate subquadrate with 2 apical setae; merus $1.2 \times$ longer than carpus; propodus $1.4 \times$ longer than carpus, 2 setae on outer distal margin; dactylus ca. $30 \%$ length of propodus, apical sensory seta on outer margin. Pereopod 4 (Fig. 7, P4): coxal plate deep, quadrate with 3 ventral marginal setae, reaching more than $50 \%$ length of basis; merus subequal in length to carpus; propodus $1.3 \times$ longer than carpus, 2 setae on outer distal margin; dactylus ca. $30 \%$ length of propodus, apical sensory seta on outer margin. Pereopod 5 (Fig. 7, P5): coxal plate bi-lobate with single seta on anteroventral margin; basis broad with posterior margin slightly convex; merus $75 \%$ length of carpus; propodus subequal to carpus, 4 setae on outer distal margin, 1 of these longer than dactylus; dactylus ca. 30\% length of propodus, apical sensory seta on outer margin. Pereopod 6 (Fig. 7, P6): subequal 


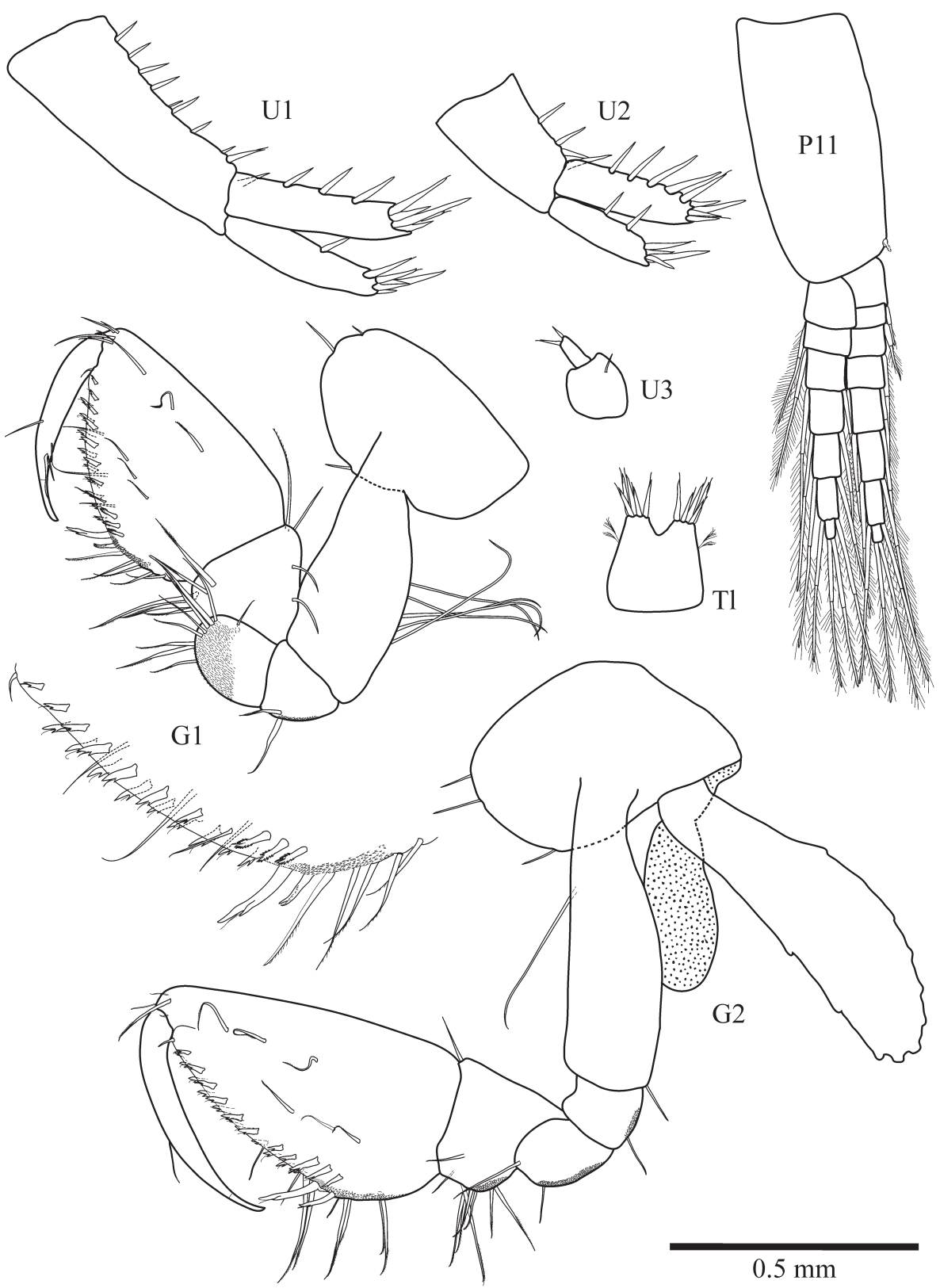

Figure 6. Stygobromus bakeri sp. nov., Holotype $\odot$ ( $4.6 \mathrm{~mm})$, John Knox Spring, Comal Co., Texas $\mathbf{G I}, \mathbf{G} 2$ gnathopods (GI palmer margin enlarged 2x) 1-2 UI-U3 uropods 1-3 PII pleopod 1 TI telson. All body parts drawn to same scale.

in length to pereopod 7 and 25\% longer than pereopod 5; coxal plate bi-lobate with single seta on posteroventral margin; basis broad with posterior margin convex; merus $90 \%$ length of carpus; propodus $1.2 \times$ longer than carpus, 1 seta on outer distal margin; 
dactylus ca. 30\% length of propodus, apical sensory seta on outer margin. Pereopod 7 (Fig. 7, P7): coxal plate ovate with single seta on ventral margin; basis broad with posterior margin convex with well developed distoposterior lobe; merus $85 \%$ length of carpus; propodus $1.2 \times$ longer than carpus, 1 long and 2 shorter setae on outer distal margin; dactylus ca. $30 \%$ length of propodus, apical sensory seta on outer margin.

Coxal gills on somites 2-7, stalked and subovate, smallest on pereopod 7 (Fig. 7 , P3-P7). Brood plates present on somites 2-5 (Fig. 6, G2; Fig. 7, P3-P5) bearing long distal setae (not illustrated). Sternal gills absent but small processes sometimes visible on sternites between pereopods 3-7.

Pleonal plates (Epimera) (Fig. 7, Plp): posterior margins weakly convex with single setule; distoposterior corners weakly rounded; ventral margin weakly convex in plate 1 and 2 and nearly straight in plate 3 , with single marginal seta on plate 2 and 2 setae on plate 3. Pleopods biramous, rami subequal, outer rami 7 segmented, inner rami 8 segmented, bearing many plumose setae, typical for genus (Fig. 6, Pl1). Uropod 1 (Fig. 6, U1): peduncle with 9-10 robust setae; inner ramus ca. 70\% length of peduncle, slightly longer than outer ramus, armed with 3 inner and 5 apical robust setae; outer ramus with 1 inner and 6 apical robust setae. Uropod 2 (Fig. 6, U2): peduncle with 4 robust setae; inner ramus subequal to peduncle, ca. $30 \%$ longer than outer ramus, armed with 5 inner and 4 apical robust setae; outer ramus with 2 inner and 4 apical robust setae. Uropod 3 (Fig. 6, U3): peduncle with single slightly distal seta; ramus ca. 51-55\% length of peduncle, with 2 apical setae. Telson (Fig. 6, Tl): quadrate (subequal in length and width) with apical v-shaped notch with depth ca. $20 \%$ length of telson, 8 to10 apical setae and bearing tufts comprised of 2 sensory setae on each lateral side.

Male $(3.1 \mathrm{~mm})$. Closely resembles female but typically smaller, with fewer setae on appendages, and differing in the following characters: Antenna 1 proportionally longer, up to $46 \%$ length of body; primary flagellum with 9 segments. Uropod 2 inner and outer rami subequal in length.

Etymology. Epithet bakeri honors David Baker, a citizen scientist, conservationist and visionary who has worked for decades to bring together scientists, politicians, funders, regulators and stakeholders from near and far to conserve the watershed of Jacob's Well. David lived immediately over the underwater cave for some time, working hard to make his own property environmentally friendly and to educate those who visited. He formed the Wimberley Valley Watershed Association, a non-profit with the mission to protect Jacob's Well and Cypress Creek.

Distribution and ecology. To date, this small species has been collected in 2 karst springs in southwestern Hays and northwestern Comal counties, Texas, a single karst spring $50 \mathrm{~km}$ northeast, on the shoreline of the Colorado River (usually emerging beneath a boat dock in Lake Austin) in Austin, Travis County, Texas and 2 karst spring complexes $74 \mathrm{~km}$ further northeast in Salado, Bell County, Texas (Fig. 1). All 4 sites are hydrogeologically distinct.

Jacob's Well (Fig. 2A-C) is a natural spring and cave located in the bed of Cypress Creek with enterable passage typically $1-2 \mathrm{~m}$ in diameter, and mapped using cave SCUBA to about $42 \mathrm{~m}$ deep and $1.6 \mathrm{~km}$ in length. Water issues out of the cave from Glen Rose Limestone (Middle Trinity Aquifer) and flows down Cypress Creek: a 


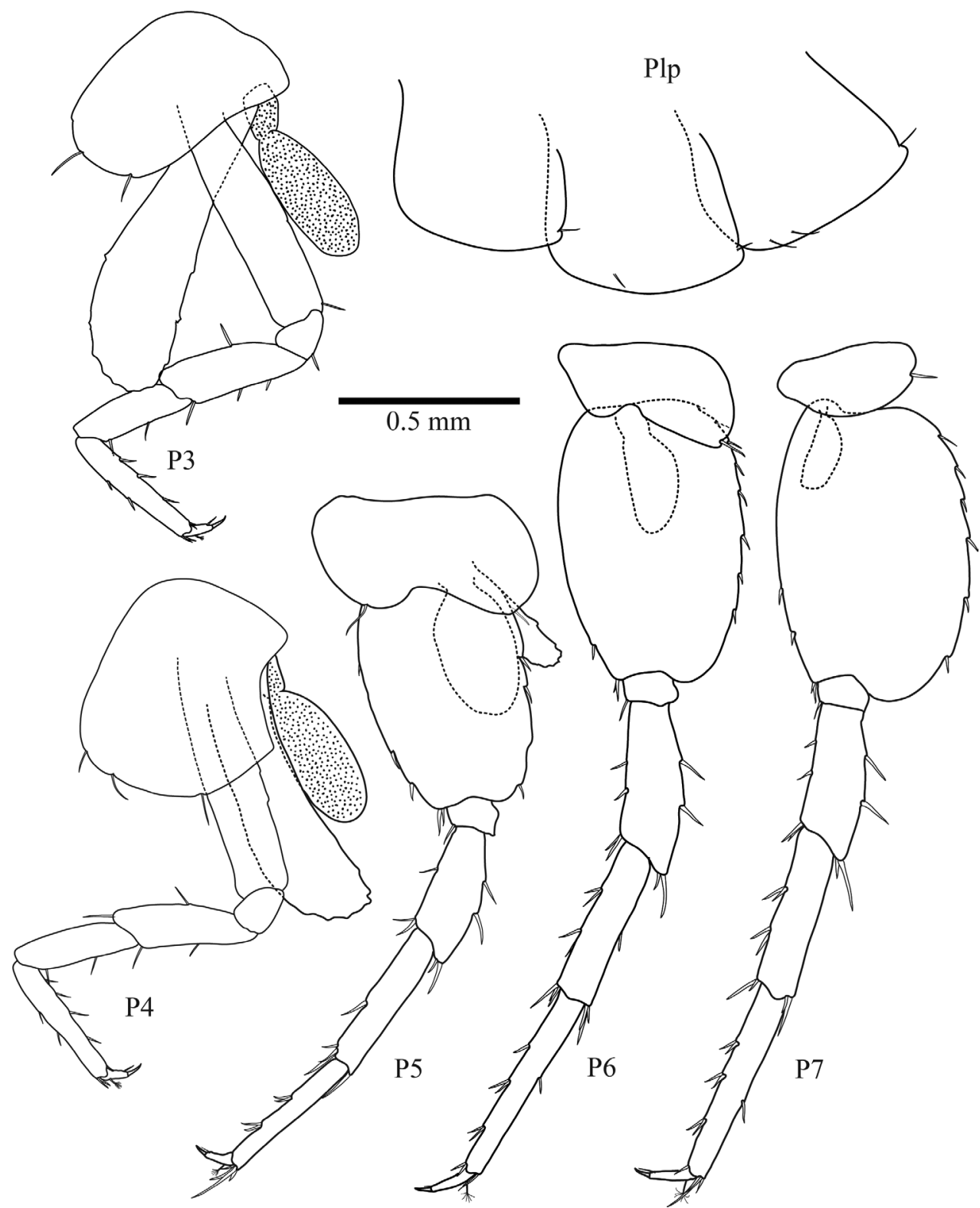

Figure 7. Stygobromus bakeri sp. nov., Holotype ${ }^{\circ}(4.6 \mathrm{~mm})$, John Knox Spring, Comal Co., Texas. P3-P7 pereopods 3-7 PIp pleonal plates (epimera).

tributary of the Blanco River (Gary et al. 2019). Stygobromus bakeri sp. nov. was only sampled successfully by hand, with divers using basters, dipnets, and centrifuge vials. Typically, the species was seen in the water column or on the floor, which consisted of silt, breakdown and cobble. Drift nets, bottle traps and cotton lures were not effective at capturing this species at Jacob's Well. It was seen only in a deeper portion of the cave between $70 \mathrm{~m}$ and $215 \mathrm{~m}$ penetration. At $70 \mathrm{~m}$ penetration, the cave passage descends 
from $-30 \mathrm{~m}$ to $-42 \mathrm{~m}$ through a vertical slot called "The Knife Edge", beyond which, S. bakeri sp. nov. was collected. But beyond $215 \mathrm{~m}$, the passage ascends back to $30 \mathrm{~m}$ and the species was not observed in that section. The habitat was not obviously different in the areas where the species was observed, with the exception of the entrance area (within $70 \mathrm{~m}$ of the surface) that has both surface influence and passage constrictions with greater flow, leading to smooth, scoured rocks and less silt.

John Knox Spring (Fig. 2D, E) emerges from Lower Glenn Rose Limestone (Middle Trinity Aquifer) through a $0.3 \mathrm{~m}$ vertical crevice-like orifice 1 meter below the water surface and along the bank of a limestone grotto pool forming the headwaters of Carper's Creek which discharges into the Blanco River. Interstitial surface insect fauna collected from this spring along with Stygobromus russelli (the most widespread Stygobromus species in central Texas) suggests that some portion of the flow might arise from hyporheic or vadose origin. Details of this habitat are described in Külköylüoğlu and Gibson (2018).

Robertson Springs (Fig. 3A-D) and Downtown Spring Complex (Fig. 3E, F) are $0.4 \mathrm{~km}$ apart, located on opposite sides of Interstate Highway 35 in the city of Salado. Both spring complexes comprise several spring orifices issuing from Edwards and Comanche Peak limestones forming spring runs that empty into Salado Creek. A diverse interstitial groundwater fauna (Table 1) including relatively widespread species has been recorded from these springs. Stygobromus bakeri sp. nov. was initially sampled by drift netting at Middle Robertson Springs (Norris et al. 2012). Robertson Springs has numerous spring openings (over 30 sites mapped during high flows) with variable discharge and substrate issuing from both banks and from under the $300 \mathrm{~m}$ long spring run. Stygobromus bakeri sp. nov. was collected at 4 spring sites throughout the run at different spring zones within the Robertson Springs complex (Diaz et al. 2016; Diaz and Warren 2019). The upper springs cease flowing seasonally and often produce troglofauna (terrestrial cave fauna) when flows resume after adequate rain events, while the lower springs are perennial and occasionally produce troglofauna. The Downtown Spring Complex is more discrete than Robertson Springs, with each of the 7 spring sites issuing from a single origin. Most of the springflow issues from Big Boiling Spring and flows down a short 5 meter spring run that empties into Salado Creek. Anderson Spring is $350 \mathrm{~m}$ downstream of Big Boiling Spring, has much less flow, issues from a fissure underneath a spring run $(250 \mathrm{~m}$ downstream of the headwater Critchfield Spring), and flows $21 \mathrm{~m}$ before joining Salado Creek (Norris et al. 2012). Hydrological studies of this area in the Northern Segment of the Edwards Aquifer showed the Downtown Spring Complex to be part of an integrated fracture system with groundwater flow velocities recorded at $1.8 \mathrm{~m} / \mathrm{sec}$ and confirmed mixing of groundwater and Salado Creek surface water at Big Boiling Spring (Wong and Yelderman 2017).

Mormon Spring \# 3 (Fig. 2F, G), which normally lies beneath Lake Austin on the Colorado River, issues from Fredericksburg Group consolidation (limestone, dolomite, chert, and marl). Lake Austin was constructed in 1940, replacing the damaged Austin Dam, which may have also inundated the spring. From time to time, the Lower Colorado River Authority lowers the level of Lake Austin to allow for dock maintenance. During the last such lowering of $3 \mathrm{~m}$ in January 2017, multiple spring 
Table I. Groundwater fauna collected at each Stygobromus bakeri sp. nov. site. Stygobionts (S) are hypogean and colonize various groundwater habitats. Crenobionts $(\mathrm{C})$ are epigean and preferentially colonize springs.

\begin{tabular}{|c|c|c|c|c|c|}
\hline Taxon & 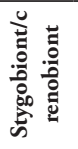 & 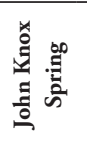 & 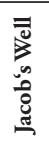 & 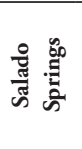 & 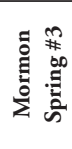 \\
\hline \multicolumn{6}{|l|}{ Turbellarians } \\
\hline \multicolumn{6}{|l|}{ Order Tricladida } \\
\hline \multicolumn{6}{|l|}{ Family Kenkiidae } \\
\hline Sphalloplana mohri Hyman, 1938 & $S$ & $\mathrm{X}$ & & & \\
\hline \multicolumn{6}{|l|}{ Annelids } \\
\hline \multicolumn{6}{|l|}{ Order Lumbriculata } \\
\hline \multicolumn{6}{|l|}{ Family Lumbriculidae } \\
\hline Eremidrilus sp. 1 Fend \& Rodriguez, 2003 & $S$ & $\mathrm{X}$ & $\mathrm{X}$ & & \\
\hline Eremidrilus $\mathbf{s p .} \mathbf{2}$ & $S$ & & $\mathrm{X}$ & & \\
\hline \multicolumn{6}{|l|}{ Molluscans } \\
\hline \multicolumn{6}{|l|}{ Order Gastropoda } \\
\hline \multicolumn{6}{|l|}{ Family Cochliopidae } \\
\hline Phreatoceras taylori (Hershler \& Longley, 1986) & $S$ & & $\mathrm{X}$ & & \\
\hline Phreatodrobia conica Hershler \& Longley, 1986 & $S$ & & $\mathrm{X}$ & & \\
\hline Phreatodrobia micra (Pilsbry \& Ferriss, 1906) & $S$ & & $\mathrm{X}$ & & \\
\hline Phreatodrobia nugax (Pilsbry \& Ferriss, 1906) & $S$ & $\mathrm{X}$ & $\mathrm{X}$ & & \\
\hline Stygopyrgus bartonensis Hershler \& Longley, 1986 & $S$ & & & $\mathrm{X}$ & \\
\hline \multicolumn{6}{|l|}{ Family Hydrobiidae } \\
\hline Marstonia comalensis (Pilsbry \& Ferriss, 1906) & $\mathrm{C}$ & $\mathrm{X}$ & $\mathrm{X}$ & $\mathrm{X}$ & \\
\hline \multicolumn{6}{|l|}{ Family Plueroceridae } \\
\hline Elimia comalensis (Pilsbry, 1890) & $\mathrm{C}$ & & $\mathrm{X}$ & $\mathrm{X}$ & \\
\hline \multicolumn{6}{|l|}{ Crustaceans } \\
\hline \multicolumn{6}{|l|}{ Order Amphipoda } \\
\hline \multicolumn{6}{|l|}{ Family Parabogidiellidae } \\
\hline Parabogidiella americana Holsinger, 1980 & S & & & $\mathrm{X}$ & \\
\hline \multicolumn{6}{|l|}{ Family Crangonyctidae } \\
\hline Stygobromus bifurcatus (Holsinger, 1967) & $S$ & & $\mathrm{X}$ & $\mathrm{X}$ & $\mathrm{X}$ \\
\hline Stygobromus russelli (Holsinger, 1967) & $S$ & $\mathrm{X}$ & $\mathrm{X}$ & $\mathrm{X}$ & $\mathrm{X}$ \\
\hline Stygobromus (flagellatus group) sp. nov. Cope, 1872 & $S$ & & $\mathrm{X}$ & & \\
\hline \multicolumn{6}{|l|}{ Order Bathynellacea } \\
\hline \multicolumn{6}{|l|}{ Family Parabathynellidae } \\
\hline Texanobathynella bowmani Delamare Deboutteville, Coineau \& Serban, 1975 & S & & & $\mathrm{X}$ & \\
\hline \multicolumn{6}{|l|}{ Order Isopoda } \\
\hline \multicolumn{6}{|l|}{ Family Asellidae } \\
\hline Caecidotea bilineata Lewis \& Bowman, 1996 & S & & & $\mathrm{X}$ & \\
\hline Caecidotea reddelli (Steeves, 1968) & S & & & $\mathrm{X}$ & $\mathrm{X}$ \\
\hline Lirceolus bisetus (Steeves, 1968) & & & & $\mathrm{X}$ & \\
\hline Lirceolus hardeni (Lewis \& Bowman, 1996) & S & $\mathrm{X}$ & $\mathrm{X}$ & $\mathrm{X}$ & \\
\hline Lirceolus pilus (Steeves, 1968) & $S$ & & $\mathrm{X}$ & $\mathrm{X}$ & \\
\hline \multicolumn{6}{|l|}{ Order Podocopida } \\
\hline Family Candonidae & & & & & \\
\hline Comalcandona tressleri Külköylüoğlu \& Gibson, 2018 & S & $\mathrm{X}$ & & & \\
\hline Schornikovdona bellensis Külköylüoğlu, Yavuzatmaca, Akdemir, Diaz \& Gibson, 2017 & S & & $\mathrm{X}$ & & \\
\hline Pseudocandona albicans (Brady, 1864) & $\mathrm{C}$ & $\mathrm{X}$ & & & \\
\hline Pseudocandona cf semicognita (Schäfer, 1934) & $\mathrm{C}$ & $\mathrm{X}$ & & & \\
\hline Physocypria cf globula Furtos, 1933 & $\mathrm{C}$ & $\mathrm{X}$ & & & \\
\hline Darwinula stevensoni (Brady \& Robertson, 1870) & $\mathrm{C}$ & $\mathrm{X}$ & & & \\
\hline Cypridopsis sp. (Brady, 1867) & $\mathrm{C}$ & $\mathrm{X}$ & & & \\
\hline Physocypria denticulata (Daday, 1905) & $\mathrm{C}$ & & & $\mathrm{X}$ & \\
\hline Chlamydotheca texasiensis (Baird, 1862) & $\mathrm{C}$ & & & $\mathrm{X}$ & \\
\hline Cypridopsis cf helvetica Kaufmann, 1900 & $\mathrm{C}$ & $\mathrm{X}$ & & & \\
\hline
\end{tabular}




\begin{tabular}{|c|c|c|c|c|}
\hline Taxon & 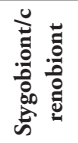 & 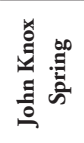 & 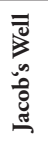 & 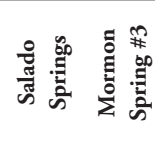 \\
\hline \multicolumn{5}{|l|}{ Arachnids } \\
\hline \multicolumn{5}{|l|}{ Order Trobidiformes } \\
\hline \multicolumn{5}{|l|}{ Family Arrenuridae } \\
\hline Arrenurus spp. Dugès, 1834 & $\mathrm{~s}$ & $\mathrm{X}$ & $\mathrm{X}$ & \\
\hline \multicolumn{5}{|l|}{ Insects } \\
\hline \multicolumn{5}{|l|}{ Order Coleoptera } \\
\hline \multicolumn{5}{|l|}{ Family Dytiscidae } \\
\hline Sanilippodytes sp. Franciscolo, 1979 & $\mathrm{C}$ & $\mathrm{x}$ & $\mathrm{X}$ & \\
\hline Uvarus texanus (Sharp, 1882) & $\mathrm{C}$ & & $\mathrm{x}$ & \\
\hline \multicolumn{5}{|l|}{ Family Elmidae } \\
\hline Microcyloepus pusillus (LeConte, 1852) & $\mathrm{C}$ & $\mathrm{x}$ & $\mathrm{X}$ & $\mathrm{X}$ \\
\hline \multicolumn{5}{|l|}{ Salamanders } \\
\hline \multicolumn{5}{|l|}{ Order Urodela } \\
\hline \multicolumn{5}{|l|}{ Family Plethodontidae } \\
\hline Eurycea chisholmensis Chippindale, Price, Wiens \& Hillis, 2000 & $\mathrm{C}$ & & & $\mathrm{x}$ \\
\hline Eurycea pterophila Burger, Smith \& Potter, 1950 & $\mathrm{C}$ & $\mathrm{x}$ & $\mathrm{x}$ & \\
\hline
\end{tabular}

complexes were visible over a stretch of about $100 \mathrm{~m}$ along the east shore of the lake. North to south, Mormon Springs numbers 1 and 2 emerged from sediment, without visible bedrock apertures. Mormon Spring \# 3 consists of multiple bedrock outlets in a cutbank excavated in bedrock below a boat dock. The spring appears associated with the Trinity Aquifer but is located near the Edwards Aquifer boundary and could potentially be a gravity spring from local recharge intersected by the Colorado River. Alternatively, this spring could represent flow from the north, from the Balcones Escarpment. No dye tracing has been conducted at this spring to characterize its springshed.

Stygobromus bakeri sp. nov. co-occurs with S. russelli (all sites), S. bifurcatus (Jacob's Well, Salado Springs, and Mormon Springs), and a large undescribed species of Stygobromus in the flagellatus group (Jacob's Well). The presence of 4 Stygobromus species at Jacob's Well is notable, and presumably all 4 species occupy different ecological niches. Due to its unusually small size and robust body, S. bakeri sp. nov. is able to inhabit both deep cave and shallow spring habitats. It may also occupy interstitial habitats such as the hyporheic zone of surface streams, although it was not collected in hyporheic samples from Carper's Creek, near John Knox Spring. The small adult size and general stout teardrop body shape is reminiscent of Seborgia relicta Holsinger, 1980 and S. hershleri Holsinger, 1992 found in groundwater habitats (deep aquifer caves and wells, springs, and hyporheos) throughout the Edwards Plateau and Balcones Escarpment. Seborgia has not been found associated with the Glen Rose formation of the Trinity Aquifer nor with the northernmost section of the Edwards Aquifer extending north of the Colorado River in Austin to Salado where Stygobromus bakeri sp. nov. occurs (Fig. 1). The furthest northern record for Seborgia relicta is from Cold Spring issuing from the Edwards Aquifer on the southern bank of the Colorado River (Ladybird Johnson Lake) only $4 \mathrm{~km}$ downstream of Mormon Spring \#3. Groundwater fauna records for Stygobromus bakeri sp. nov. sites (Table 1) include interstitial and relatively widespread, ecological generalist stygobionts 
and crenobionts, yet widespread cavernicolous stygobionts such as Cirolanides spp. isopods are absent at these sites (Holsinger 1967; Lewis 2000; Krejca 2009; Gibson et al. 2018; Hutchins 2018; Devitt et al. 2019; Schwartz et al. 2019; Alvear et al. 2020). Many of the springs have been thoroughly sampled and regularly monitored for multiple years, so the stygofauna is better characterized relative to many other Texas groundwater sites.

\section{Key to Texas species of Stygobromus adapted from Holsinger (1967)}

Species lengths reported from original descriptions for relative comparisons and likely vary.

1a Gnathopod 2 longer than gnathopod 1 2, hubbsi group

1b Gnathopod 1 longer or subequal to gnathopod 2 3

2a Pereopod 6 and 7 basis broadly expanded posteriorly with dorsoposterior lobe, adults $<6 \mathrm{~mm}$ long, central Texas

S. bakeri sp. nov. Gibson \& Hutchins

$2 \mathrm{~b} \quad$ Pereopod 6 and 7 basis narrow, distoposterior lobe poorly developed, adults $\leq 13 \mathrm{~mm}$ long, rare, Culberson County, west Texas.

S. limbus Wang \& Holsinger, 2001

3a Gnathopod 1 often stouter but subequal in length to gnathopod 2, pereopod 6 and 7 subequal in length.

$3 \mathrm{~b} \quad$ Gnathopod 1 stouter and usually longer that gnathopod 2, pereopod 7 longer than pereopod 6 .

8, tenuis group

4a Pereopod 4 coxal plate extending distally $>1 / 2$ length of basis, pereopod 5-7 basis broadly expanded posteriorly, well defined distoposterior lobe, midwest Texas.

S. hadenoecus (Holsinger, 1966)

$4 \mathrm{~b} \quad$ Pereopod 4 coxal plate extending distally $<1 \frac{1}{2}$ length of basis, pereopod 5-7 basis posterior margin not entirely expanded, usually narrow or narrows distally with poorly defined distoposterior lobes, central Texas

5, flagellatus group

5a Uropod 3 with $\leq 3$ apical setae, gnathopod 1 palmer margin straight or convex, telson with or without lateral setae, medium to large size (11-15 mm long).

5b Uropod 3 typically with $\geq 4$ apical setae, gnathopod 1 palmer margin convex, telson without lateral setae, medium size $(8-11 \mathrm{~mm}$ long).

6a Pereopod 5 basis subtriangular (expanded proximally), gnathopod 1 palmer margin convex with 2 rows each with many (ca. 20) robust bifurcated setae, pereopod 7 dactylus $1 / 4$ length of propodus, telson often with multiple lateral setae (3 pair typical in females), large $\leq 15 \mathrm{~mm}$ long

\section{S. flagellatus (Benedict, 1896)}

6b Pereopod 5 basis narrow (parallel sided), gnathopod 1 palmer margin straight, with 2 rows each with fewer (ca. 10) relatively stouter robust bifurcated setae, 
pereopod 7 dactylus $1 / 3$ length of propodus, telson sometimes with single pair of lateral setae, medium $\leq 11 \mathrm{~mm}$ long.... S. longipes (Holsinger, 1966)

7a Pereopods 5-7 dactylus $1 / 3$ length of propodus; uropod 3 with 3 or 4 apical setae, $\leq 8 \mathrm{~mm}$ long, rare, Kendall and northern Bexar counties.

S. dejectus (Holsinger, 1967)

7b Pereopods 5-7 dactylus $1 / 4$ length of propodus; uropod 3 with 5 apical setae, $\leq 11 \mathrm{~mm}$ long, rare, Comal County.

S. pecki (Holsinger, 1967)

8a Gnathopod palmer margins deeply concave (pronounced in larger specimens)

8b Gnathopod palmer margins straight to convex.

9a Lateral sternal gills simple, rare, central Texas, $\leq 16 \mathrm{~mm}$ long

9b Lateral sternal gills bifurcated, widespread in northern Texas, $\leq 10 \mathrm{~mm}$ long

S. balconis (Hubricht, 1943)

S. alabamensis (Stout, 1911)

10a Gnathopod 1 palmer margin convex, large (recorded $>14 \mathrm{~mm}$ long) widespread in central Texas .............................. S. bifurcatus (Holsinger, 1967)

10b Gnathopod 1 palmer margin straight, medium to large ...........................11

11a Pereopod 5-7 slender (pereopod 7 carpus width ca. 15\% that of length), pereopod $7 \mathrm{ca} .25 \%$ longer than pereopod 5, pereopod 7 basis posterior margin mostly straight (parallel sided), uropod 3 with 3 apical setae, telson with ca. 14 apical setae, large ( $\leq 14 \mathrm{~mm}$ long) rare, San Saba County.....

S. reddelli (Holsinger, 1966)

11b Pereopod 5-7 less slender (pereopod 7 carpus width ca. 25\% that of length), pereopod $7 \geq 30 \%$ longer than pereopod 5 , pereopod $5-7$ basis posterior margin mostly convex, telson with ca. 11 apical setae, medium sized $(\leq 12$ $\mathrm{mm}$ long) widespread in central Texas.

S. russelli (Holsinger, 1967)

\section{Discussion}

The description of $S$. bakeri sp. nov. represents a southeast extension of the known range of the hubbsi group into the eastern Edwards Plateau and Balcones Escarpment of central Texas. Stygobromus putealis, described from eastern Wisconsin is the only other representative of the hubbsi group that occurs east of the western Cordillera of North America (Wang and Holsinger 2001). The presence of this species at Robertson Springs, over $70 \mathrm{~km}$ away from the other nearest known site for the species is somewhat unusual not only because of the distance, but because the sites are discharge points for 2 distinct karst aquifers, the Trinity and Edwards. However, at least 3 other Stygobromus species (S. bifurcatus, S. longipes, S. russelli) also occur in both the Trinity and Edwards aquifers, and limited, localized hydrologic connections between these aquifers have been documented (Tian et al. 2020), opening the possibility of interaquifer dispersal. Additionally, numerous members of the hubbsi group have been recorded from the hyporheic zone of surface streams (Wang and Holsinger 2001) which 
could provide another potential avenue for dispersal by $S$. bakeri sp. nov. While the current range of $S$. bakeri sp. nov. is within the range reported for other Stygobromus species (Hutchins 2018) and certainly within the $200 \mathrm{~km}$ range reported for macrostygobionts by Trontelj et al. (2009), genetic analysis would still be prudent to evaluate whether southern and northern populations represent cryptic lineages.

At all sites where $S$. bakeri sp. nov. was detected, it occurs in apparently low abundance, particularly compared to co-occurring Stygobromus (e.g. at John Knox Spring, S. bakeri sp. nov. composed 10\% of all Stygobromus (27 versus 236 S. russelli) collected from 6 January to 21 May 2010. In comparison, at Robertson Springs, the highest yearly abundance of $S$. bakeri sp. nov. was 5\% of all Stygobromus (26 versus 532 S. russelli and S. bifurcatus combined) collected from 12 April to 7 November 2018. However, it is uncertain whether perceived rarity reflects actual rarity or a lack of effective sampling (Niemiller et al. 2018). Indeed, we lack much basic ecological information about the species including niche breadth and microhabitat preference. A better understanding of the species' rarity and distribution is a high priority given growing threats to water quantity and water quality in the region.

Both Jacob's Well and John Knox Springs are fed by the Trinity Aquifer, although the recharge area for John Knox Spring has not been delineated. Recharge for Jacob's Well primarily occurs in an $80 \mathrm{~km}^{2}$ area within the Dry Cypress Creek watershed northwest of the spring (Gary et al. 2019). Increased pumping in the region has resulted in reduced spring flow at Jacob's Well, which now flows intermittently (Hunt et al. 2013), and projected rapid human population growth in the region will put additional pressures on groundwater resources. Hays County is the $3^{\text {rd }}$ fastest growing county, by percent, in Texas (Texas Demographic Center 2019). Desired future conditions set by Groundwater Management Area 9 allow for an increase in average drawdown of the Trinity Aquifer in the region up to approximately $9 \mathrm{~m}$ by 2060, which if realized, would result in reduced spring flow or spring failure for many Trinity-fed springs. A Recharge Study Zone created in January 2020 and a proposed Jacob's Well Groundwater Management Zone afford some pumping curtailments and restrictions on new well construction in the region. Neither of these zones, however, provides conservation benefits for the John Knox Spring springshed, which probably occurs farther west in adjacent Comal County, Texas. Texas Parks and Wildlife Department recorded discharge measurements of 28-57 L/s at Carper's Creek in 2005, 2007, and 2010 (Chad Norris, pers. comm.) and the springshed proportional to this discharge is assumed to be approximately 13-18 km² (Marcus Gary, Edwards Aquifer Authority, pers. comm.).

The listing of several aquifer-obligate species in the adjacent Edwards Aquifer in the 1960s, 1970s, and 1980s spurred formation of the Edwards Aquifer Authority (EAA) in 1993. Charged with protecting minimum spring flows at Comal and San Marcos springs, the EAA implemented programs that helped protect groundwater recharge and reduce groundwater use (including enforcement of pumping limitations). The regulatory actions of the EAA and conservation measures established in the Edwards Aquifer Habitat Conservation Plan (HCP) have been successful in maintaining spring flow despite a rapidly growing population. Indeed, existing models predict that 
HCP conservation measures are sufficient to maintain springflows during drought-ofrecord conditions that would otherwise result in spring failure (Votteler and Gulley 2014). However, EAA jurisdiction does not cover sites at which S. bakeri sp. nov. occurs. Although similar regulatory frameworks do not exist for the Jacob's Well and John Knox Springs area, the proposed management practices outlined by the Jacob's Well Groundwater Management Zone were designed explicitly to maintain springflow during periods of drought (Gary et al. 2019).

Recharge of the northern section of the Edwards Aquifer and groundwater conservation in Salado is not regulated by the EAA. In this section of the aquifer, Clearwater Underground Water Conservation District is responsible for management of groundwater in Bell County. Recharge for the springs where S. bakeri sp. nov. and the federally threatened salamander, Eurycea chisholmensis occur are thought to be in the west and southwest portion of Bell County with flow moving generally southeast (Wong and Yelderman 2017). In addition, Brune hypothesized that the recharge to Salado Creek began from fissures along the Williamson and Bell county line (Brune 1981). Bell County is the most northern extension of the Edwards Aquifer in Texas (Wong and Yelderman 2017) and the most northern location known for many Edwards Aquifer associated taxa (Alvear et al. 2020). Edwards limestones thin in Bell County relative to areas to the south, and the southeastern extent of the county was described as being devoid of substantial caves (McKenzie and Reddell 1964).

Mormon Springs is located upstream, but near habitat for the federally endangered Barton Springs and Austin blind salamanders (Eurcyea sosorum Chippindale, Price \& Hillis, 1993 and E. waterlooensis Hillis, Chamberlain, Wilcox \& Chippindale, 2001), and is in the same aquifer formation as the federally endangered Jollyville Plateau salamander, E. tonkawae Chippindale, Price, Wiens \& Hillis, 2000. Little is known about groundwater flow on the northeast side of the Colorado River on the Balcones Escarpment. Mormon Springs is not within a groundwater conservation district, and well pumping, mainly for domestic landscaping use, is unregulated.

\section{Conclusion}

The discovery of an undescribed Stygobromus amphipod from the Trinity and Edwards aquifers associated karst springs in Hays, Comal, Travis, and Bell counties in central Texas is unsurprising giving the high species richness and small-range endemism previously reported for the genus and previous documentation of numerous undescribed taxa (Holsinger et al. 2011). However, the assignment of S. bakeri sp. nov. to the predominantly western hubbsi group suggests that the hubbsi group may be more widespread than currently recognized and that additional investigation for smallbodied taxa west of the continental divide will yield additional undescribed species. Stygobromus bakeri sp. nov. is the $12^{\text {th }}$ Stygobromus species described from Texas and can be distinguished from other Texas congeners by gnathopod 2 larger than gnathopod 1 and pereopods 6 and 7 with broadly expanded bases and distinct distoposterior lobes. 
Stygobrumus bakeri sp. nov. is distinguished from all other hubbsi group species by gnathopod 1 and 2 with 2 rows of 3 singly inserted setae on the inner palm, gnathopod 1 with row of 4-5 setae posterior to the defining angle, and uropod 3 with single, slightly distal peduncular seta. Molecular analysis is recommended to assess the relatedness of southern Trinity Aquifer populations versus northern Edwards Aquifer populations. Finally, the description of small-range endemic species in the region underscores the immediate need for a comprehensive groundwater management framework that ensures adequate groundwater habitat in the face of drought exacerbated by a changing climate and growing human populations.

\section{Acknowledgements}

Thanks to the land managers at Jacob's Well for access to SCUBA and collection in the cave. James Brown and Gregg Tatum are cave divers that helped with cave diving logistics and collection of specimens and assisted author JKK with very technical SCUBA sampling, Krista McDermid helped process specimens. Special thanks to David Baker for logistical support and his decades-long dedication to the conservation of Jacob's Well. We thank John Knox Ranch for the continual access to their property and their dedication to environmental education and preservation of one of the most pristine streams in the Texas Hill Country, The Robertson family and the Bell County Adaptive Management Coalition for support of conservation research and access to springs, wells, and caves in the area. We greatly appreciate the taxonomic expertise provided by Will Coleman, Steve Fend, Robert Hershler, Okan Külköylüoğlu, Kathryn Perez, and Ian Smith, and specialized knowledge from hydrologist Marcus Gary and field biologists, Andy Gluesenkamp, Jessica Gordon, Chad Norris, James Reddell, Jennifer Bronson Warren, and staff at the San Marcos Aquatic Resources Center.

The views presented herein are those of the authors and do not necessarily represent those of the U.S. Fish and Wildlife Service.

\section{References}

Alvear DA, Diaz P, Gibson R, Hutchins BT, Schwartz B, Perez KE (2020) Expanding the known ranges of the phreatic snails (Mollusca, Gastropoda, Cochlicopidae) of Texas, USA. Freshwater Mollusk Biology and Conservation 23: 1-17. https://doi.org/10.31931/fmbc. v22i2.2020.1-17

Aunins AW, Nelms DL, Hobson CS, King TL (2016) Comparative mitogenomic analyses of three North American stygobiont amphipods of the genus Stygobromus (Crustacea: Amphipoda). Mitochondrial DNA Part B 1: 560-563. https://doi.org/10.1080/23802359.2 016.1174086

Baird W (1862) Description of some new species of entomostraous Crustacea. Annals and Magazine of Natural History Series 3: 1-6. https://doi.org/10.1080/00222936208681270 
Benedict JE (1896) Preliminary descriptions of a new genus and three new species of crustaceans from an artesian well at San Marcos, Texas. Proceedings of the United States National Museum 18: 615-617. https://doi.org/10.5479/si.00963801.18-1087.615

Brady GS (1864) On species of Ostracoda new to Britain. Annals and Magazine of Natural History 13: 59-64. https://doi.org/10.1080/00222936408681574

Brady GS (1867) A synopsis of the recent British Ostracoda. Intellect Observer 12: 110-130. Brady GS, Robertson D (1870) The Ostracoda and Foraminifera of tidal rivers. Annals and Magazine of Natural History 6: 1-33. https://doi.org/10.1080/00222937008696200

Brune G (1981) Springs of Texas. Branch-Smith, Inc, Fort Worth, Tex, 566 pp. https://www. edwardsaquifer.org/?s=Springs+of+Texas+Volume+I+

Burger WL, Smith HM, Potter Jr EE (1950) Another neotenic Eurycea from the Edwards Plateau. Proceedings of the Biological Society of Washington 63: 51-58. https://www. biodiversitylibrary.org/page/35878983\#page/287/mode/1 up

Burri NM, Weatherl R, Moeck C, Schirmer M (2019) A review of threats to groundwater quality in the Anthropocene. Science of the Total Environment 684: 136-154. https://doi. org/10.1016/j.scitotenv.2019.05.236

Cannizzaro A, Balding GD, Stine M, Sawicki TR (2019) A new syntopic species of Stygobromus Cope, 1872 (Amphipoda: Crangonyctidae) from groundwaters in Georgia and Florida, USA, with notes on S. floridanus Holsinger and Sawicki, 2016. Journal of Crustacean Biology 39: 407-418. https://doi.org/10.1093/jcbiol/ruz034

Chippindale PT, Price AH, Hillis DM (1993) A new species of perennibranchiate salamander (Eurycea, Plethodontidae) from Austin, Texas. Herpetologica 49: 242-259. http://www. zo.utexas.edu/faculty/antisense/papers/Herpetologica1993.pdf

Chippindale PT, Price AH, Wiens JJ, Hillis DM (2000) Phylogenetic relationships and systematic revision of central Texas hemidactyliine plethodontid salamanders. Herpetological Monographs 14: 1-80. https://doi.org/10.2307/1467045

Cope ED (1872) On the Wyandotte Cave and its fauna. American Naturalist 6: 406-422. https://doi.org/10.1086/270970

Culver DC, Pipan T (2015) Shifting paradigms of the evolution of cave life. Acta Carsologica 44: 415-425. https://doi.org/10.3986/ac.v44i3.1688

Daday E (1905) Untersuchungen über die Süsswasser-Mikrofauna Paraguays. IV. Ostracoda. Zoologica 44: 234-27. https://www.zobodat.at/pdf/Zoologica_18_44_0001-0374.pdf

de Graaf IEM, Gleeson T, van Beek LPH, Sutanudjaja EH, Bierkens MFP (2019) Environmental flow limits to global groundwater pumping. Nature 574: 90-94. https://doi. org/10.1038/s41586-019-1594-4

Delamare Deboutteville, C, Coineau N, Serban E (1975) Decouverte de la famille des Parabathynellidae (Bathynellacea) en Amerique du Nord: Texanobathynella bowmani n.g. n.sp.-Comptes Rendus Hebdomadaires de I' Academie des Sciences, Paris, Serie D 280: 2223-2226.

Devitt T (2019) Creatures of the deep karst. American Scientist 10: 260-262. https://doi. org/10.1511/2019.107.5.260

Devitt TJ, Wright AM, Cannatella DC, Hillis DM (2019) Species delimitation in endangered groundwater salamanders: Implication for aquifer management and biodiversity conserva- 
tion. Proceedings of the National Academy of Sciences of the United States of America 116: 2624-2633. https://doi.org/10.1073/pnas.1815014116

Derzhavin AN (1945) The subterranean amphipoda of Transcaucasus. Bulletin of the Academy of Sciences of Azerbaijan SSR 8: 27-43.

Diaz PH, Montagne M, Gibson R (2016) Salado salamander monitoring final report 2016. Texas Fish and Wildlife Conservation Office, United States Fish and Wildlife Service and Texas Fish and Wildlife Department report submitted to the Bell County Adaptive Management Coalition.

Diaz PH, Warren JB (2019) Salado salamander monitoring final report 2019. Texas Fish and Wildlife Conservation Office, United States Fish and Wildlife Service and Texas Fish and Wildlife Department report submitted to the Bell County Adaptive Management Coalition.

Dugès A (1834) Recherches sur l'ordre des Acariens en général et la famille de Trombidiés en particulier. Premier Mémoire. Annales des Sciences Naturelles, Zoologie et Biologie Animale 2: 5-46.

Eberhard SM, Halse SA, Williams MR, Scanlon MD, Cocking J, Barron JJ (2009) Exploring the relationship between sampling efficiency and short-range endemism for groundwater fauna in the Pilbara region, Western Australia. Freshwater Biology 54: 885-901. https:// doi.org/10.1111/j.1365-2427.2007.01863.x

Ethridge JZ, Gibson JR, Nice CC (2013) Cryptic diversity within and amongst spring-associated Stygobromus amphipods (Amphipoda: Crangonyctidae). Zoological Journal of the Linnean Society 167: 227-242. https://doi.org/10.1111/j.1096-3642.2012.00877.x

Fend S, Rodriguez P (2003) Eremidrilus n. gen. (Annelida, Clitellata, Lumbriculidae) and new species from California, U.S.A. Canadian Journal of Zoology 81: 551-542. https://cdnsciencepub.com/doi/pdf/10.1139/z02-235?casa_token=zGBLABvJFP0AAAAA\%3AUWcJN0S 7JZZfq0YpO6kyomqmC-O3d2vtY1Tuwlv8Bz9JH0cjdZOVI49pkEueb_nYLceiTXgqJg\&

Franciscolo ME (1979) On a new Dytiscidae from a Mexican cave - a preliminary description. Fragmenta Entomologica Roma 15: 233-241. http:/www.fragmentaentomol.org/index. php/fragmenta/legacy

Furtos N (1933) The Ostracoda of Ohio. Bulletin of the Ohio Biological Survey 29: 411-524. Gary MO, Hunt BB, Smith BA, Watson JA, Wierman D (2019) Evaluation for the development of the Jacob's Well Groundwater Management Zone in Hays County, Texas. Technical Report prepared for the Hays Trinity Groundwater Conservation District, Hays County, Texas. Meadows Center for Water and the Environment, Texas State University at San Marcos, TX. Report: 2019-05. July 2019, 58 pp. http://haysgroundwater.com/files/ Documents/JW-Mgmt-Zone-Report_7.30.19.pdf

Gibson JR, Harden SJ, Fries JN (2008) Survey and distribution of invertebrates from selected springs of the Edwards Aquifer in Comal and Hays Counties, Texas. The Southwestern Naturalist 53(1): 74-84. https://doi.org/10.1894/0038-4909(2008)53[74:SADOIF]2.0.CO;2

Hay OP (1882) Notes on some fresh-water Crustacea, together with descriptions of two new species. American Naturalist 16: 143-146. [241-243.] https://www.biodiversitylibrary. org/page/41331368\#page/154/mode/1 up

Hershler R, Longley G (1986a) Hadocerus taylori, a new genus and species of phreatic Hydrobiidae (Gastropoda: Rissoacea) from south-central Texas. Proceedings of the Biological Soci- 
ety of Washington 99: 121-136. https://repository.si.edu/bitstream/handle/10088/11314/ iz_HershlerLongley1986b.pdf

Hershler R, Longley G (1986b) Phreatic hydrobiids (Gastropoda: Prosobranchia) from the Edwards (Balcones Fault Zone) Aquifer region, South-Central Texas. Malacologia 27: 127-172. https://repository.si.edu/bitstream/handle/10088/11313/iz_HershlerLongley1986a.pdf

Hillis DM, Chamberlain DA, Wilcox TP, Chippindale PT (2001) A new species of subterranean blind salamander (Plethodontidae: Hemidactyliini: Eurycea: Typhlomolge) from Austin, Texas, and a systematic revision of central Texas paedomorphic salamanders. Herpetologica 57: 266-280. https://www.jstor.org/stable/pdf/3893095.pdf?casa_ token=X2PJBzBYi0sAAAAA:_mL0dMqWtBu1uW3cY0NYhcPCoqCNY7o5TQIVQi3Djar5EK7340T78xbgRR2iRlLvhxkkjGsHSUhgzt0szoWKgvpPCvzkOWKNdIo6_ a98611SgwkN

Holmes SJ (1909) Description of a new subterranean amphipod from Wisconsin. Transactions of the Wisconsin Academy of Sciences, Arts and Letters 16: 77-80. [plates 6-7.] https:// www.biodiversitylibrary.org/page/54893572\#page/103/mode/1up

Holsinger JR (1966) Subterranean amphipods of the genus Stygonectes (Gammaridae) from Texas. The American Middland Naturalist 76: 100-124. https://www.jstor.org/stable/ pdf/2423237.pdf?casa_token=jBtwCt7qy9oAAAAA:4uT4QOZ1×TgYLdmyk0ERhdpz OZHgpl7ehJYYcJP75PrpKyjlke7v0PRfTa8eiL-j54OSMJ1LsIV2uCRSMUKoZzJMXru qNA9kEU3Exenq4Rb01ZCQ

Holsinger JR (1967) Systematics, speciation, and distribution of the subterranean amphipod genus Stygonectes (Gammaridae). Bulletin of the United States National Museum 259, 176 pp. http://scholar.google.com/scholar_url?url=https $\% 3 \mathrm{~A} \% 2 \mathrm{~F} \% 2$ Frepository.si.edu $\% 2 \mathrm{Fb}$ itstream\%2Fhandle\%2F10088\%2F10121\%2FUSNMB_2591967_unit.pdf\&hl=en\&sa $=\mathrm{T} \&$ oi $=$ gga\&ct $=$ gga\&cd $=0 \& \mathrm{~d}=3367762336529767080 \&$ ei $=\mathrm{T} 0 \mathrm{P} 2 \times$ uaTK7uB6rQPxbm DwAo\&scisig=AAGBfm0AYr2Gx054tN80Ulu6NuinN_wYew\&nossl=1 \&ws=1536x76 0\&at=Systematics $\% 2 C \% 20$ Speciation $\% 2 C \% 20$ and $\% 20$ Distribution $\% 20$ of $\% 20^{\text {th }} \mathrm{e} \% 20$ Subterranean\%20Amphipod\%20Genus\%20Styognectes\%20(Gammaridae) \&bn=1

Holsinger JR (1969) The systematics of the North American subterranean amphipod genus Apocrangonyx (Gammaridae) with remarks on ecology and zoogeography. The American Midland Naturalist 81: 1-28. https://www.jstor.org/stable/pdf/2423647.pdf?casa_token=F3vlJkv6Eb EAAAAA:4ij3PNiLldhtocaOvGGkYDfkHLL37nwcwf_MUn-cx88EJw3QsXVQXDGStwntDhmwWeIKVb79qY21oIQz6NCUpHl3NMeOHRWoG9oc91W5ivBrchmp

Holsinger JR (1974) Systematics of the subterranean amphipod genus Stygobromus (Gammaridae), Part I: Species of the Western United States. Smithsonian Contributions to Zoology 160: 1-63. https://doi.org/10.5479/si.00810282.160

Holsinger JR (1978) Systematics of the subterranean amphipod genus Stygobromus (Crangonyctidae), Part II: Species of the Eastern United States. Smithsonian Contributions to Zoology 266: 1-144. https://doi.org/10.5479/si.00810282.266

Holsinger JR, Longley G (1980) The subterranean amphipod crustacean fauna of an artesian well in Texas. Smithsonian Contributions to Zoology 308: 1-62. https://doi.org/10.5479/ si.00810282.308 
Holsinger JR, Shaw P (1987) Stygobromus quatsinensis, a new amphipod crustacean from caves on Vancouver Island, British Columbia, with remarks on zoogeographic relationships. Canadian Journal of Zoology 65: 2202-2209. https://doi.org/10.1139/z87-334

Holsinger JR (1992) Four new species of subterranean amphipod crustaceans (Artesiidae, Hadziidae, Sebidae) from Texas, with comments on their phylogenetic and biogeographic relationships. Texas Memorial Museum, Speleological Monographs 3: 1-22. http://www. nativefishlab.net/library/textpdf/19888.pdf

Holsinger JR (2009) Three new species of the subterranean amphipod crustacean genus Stygobromus (Crangonyctidae) from the District of Columbia, Maryland, and Virginia. In: Roble SM, Mitchell JC (Eds) A lifetime of contributions to myriapodology and the natural history of Virginia: A Festschrift in Honor of Richard L. Hoffman's $80^{\text {th }}$ Birthday. Virginia Museum of Natural History Special Publication 16. Martinsville, 261-276.

Holsinger JR, Ansell J, Shafer J (2011) Four new species of the subterranean amphipod genus Stygobromus (Amphipoda: Crangonyctidae) from shallow groundwater habitats on the Coastal Plain and eastern margin of the Piedmont in Maryland and Virginia, USA. Zootaxa 2972: 1-21. https://doi.org/10.11646/zootaxa.4067.1.7

Holsinger JR, Ansell L (2014) A new species of the subterranean amphipod genus Stygobromus (Amphipoda: Crangonyctidae) from two caves and a spring in western Maryland, USA with additional records of undescribed species from groundwater habitats in central Maryland. Zootaxa 3768: 386-394. https://doi.org/10.11646/zootaxa.3768.3.6

Holsinger JR, Sawicki TR (2016) A new species of the subterranean genus Stygobromus (Amphipoda: Crangonyctidae) from a cave spring in northern Florida, USA. Zootaxa 4067: 088-094. https://doi.org/10.11646/zootaxa.4067.1.7

Hubricht L (1943) Studies in the Nearctic freshwater Amphipoda, III. The American Midland Naturalist 29: 683-712. https://doi.org/10.2307/2421157

Hunt BB, Norris C, Gary M, Wierman DA, Broun AS, Smith BA (2013) Pleasant Valley Spring: A newly documented karst spring of the Texas Hill Country Trinity Aquifer. Geological Society of America Annual Meeting, South-Central Section (4-5 April) Paper No. 39-3. San Antonio, Texas.

Huston DC, Gibson JR (2018) New record of an isolated spring population of Huleechius marroni Brown, 1981 in west Texas. Southwestern Entomologist 43(3): 803-806. https://doi. org/10.3958/059.043.0328

Hutchins BT (2018) The conservation status of Texas groundwater invertebrates. Biodiversity and Conservation 27: 475-501. https://doi.org/10.1007/s10531-017-1447-0

Hyman LH (1938) Additional North American cave planarians. Anatomical Record supplement 72(4): 1-137.

Kaufmann A (1900) Neue Ostracoden aus der Schweiz. Zoologischer Anzeiger 23: 131-133.

Krejca JK (2009) New records for Cirolanides texensis Benedict 1896 (Isopoda: Cirolanidae), including possible extirpations at impacted Texas Caves. Cave and Karst Science 35: 41-46. Külköylüoğlu O, Yavuzatmaca M, Akdemir D, Diaz PH, Gibson R (2017) On Schornikovdona gen. nov. (Ostracoda, Candonidae) from rheocrene springs in Texas (U.S.A.). Crustaceana 90: 1443-1461. https://doi.org/10.1163/15685403-00003707 
Külköylüoğlu O, Gibson JR (2018) A new Ostracoda (Crustacea) genus, Comalcandona gen. nov., from Texas, USA. Turkish Journal of Zoology 42: 18-28. https://doi.org/10.3906/ zoo-1611-52

LeConte JL (1852) Synopsis of the Parnidae of the United States. Proceedings of the Academy of Natural Sciences of Philadelphia 6: 41-45. https://www.biodiversitylibrary.org/ item/17888\#page/63/mode/1up

Lewis JJ (2001) Three new species of subterranean asellids from western North America, with a synopsis of the species of the region (Crustacea: Isopoda: Asellidae). Texas Memorial Museum, Speleological Monographs 5: 1-15. https://decapoda.nhm.org/pdfs/4217/4217.pdf

Lewis JJ, Bowman TE (1996) The subterranean asellids of Texas (Crustacea: Isopoda: Asellidae). Proceedings of the Biological Society of Washington 109: 482-500. http://www. eahcp.org/files/admin-records/EARIP-HCP-docs/Lewis,\%20Bowman\%201996.pdf

McKenzie D, Reddell JR (1964) The caves of Bell and Coryell Counties. Texas Speleological Survey 2: 1-63.

Niemiller ML, Porter ML, Keany J, Gilbert JH, Fong DW, Culver DC, Hobson CS, Kendall KD, Davis MA, Taylor SJ (2018) Evaluation of eDNA for groundwater invertebrate detection and monitoring: a case study with endangered Stygobromus (Amphipoda: Crangonyctidae). Conservation Genetics Resources 10: 247-257. https://doi.org/10.1007/ s12686-017-0785-2

Nissen BD, Devitt TJ, Bendik NF, Gluesenkamp AG, Gibson R (2018) New occurrence records for stygobiontic invertebrates from the Edwards and Trinity aquifer in west-central Texas, USA. Subterranean Biology 28: 1-13. https://doi.org/10.3897/subtbiol.28.29282

Norris C, Gluesenkamp A, Singhurst J, Bradby D (2012) A biological and hydrological assessment of the Salado Springs Complex, Bell County, Texas. Texas Parks and Wildlife Department, Austin, 71 pp.

Palatov DM, Marin IN (2020) A new genus of the family Crangonyctidae (Crustacea, Amphipoda) from the Palearctic, with descriptions of two new species from the foothills of the Altai Mountains. Zoologicheskiy Zhurnal 99: 1160-1186. https://doi.org/10.31857/ S004451342010013X

Pilsbry HA (1890) Remarks on certain Goniobases. Nautilus 4: 49-50.

Pilsbry HA, Ferriss JH (1906) Mollusca of the Southwestern states, II (plates V-IX). Proceedings of the Academy of Natural Sciences of Philadelphia 58: 123-175. https://www.jstor. org/stable/pdf/4063087.pdf?refreqid=excelsior\%3Ace5503b573ef969a665fbce782d16a25

Schwartz BF, Hutchins BT, Schwartz ZG, Hess AJ, Bonett RM (2019) Cirolanides wassenichae sp. nov., a freshwater, subterranean Cirolanidae (Isopod, Cymothoida) with additional records of other species from Texas, United States. Zootaxa 4543(4): 498-514. https://doi. org/10.11646/zootaxa.4543.4.2

Sharp D (1882) On aquatic carnivorous Coleoptera or Dytiscidae. Scientific Transactions of the Royal Dublin Society 2: 179-1003. https:/www.biodiversitylibrary.org/ item/38596\#page/7/mode/1 up

Sidorov DA, Holsinger JR, Takhteev VV (2010) Two new species of the subterranean amphipod genus Stygobromus (Amphipoda: Crangonyctidae) from Siberia, with new data on 
Stygobromus pusillus (Martynov) and remarks on morphology and biogeographic relationships. Zootaxa 2478: 41-58. https://doi.org/10.11646/zootaxa.2478.1.2

Steeves HR III (1968) Three new troglobitic asellids from Texas. American Midland Naturalist 79: 183-188. https://doi.org/10.2307/2423163

Stock JH (1974) The systematics of certain Ponto-Caspian Gammaridae (Crustacea, Amphipoda). Mitteilungen Hamburg Zoologischen Museum and Institut 70: 75-95.

Stout VR (1911) A new subterranean freshwater amphipod. Pomona College Journal of Entomology 3: 569-571. https://www.biodiversitylibrary.org/item/45065\#page/199/mode/1 up

Taylor SJ, Holsinger JR (2011) A new species of the subterranean amphipod crustacean genus Stygobromus (Crangonyctidae) from a cave in Nevada, USA. Subterranean Biology 8: 39-47. https://doi.org/10.3897/subtbiol.8.1230

Texas Demographic Center (2019) Texas Population Projections 2010 to 2050. Report, Texas Demograhic Center, San Antonio, 7 pp. https://demographics.texas.gov/Resources/publications/2019/20190128_PopProjectionsBrief.pdf

Tian L, Smith BA, Hunt BB, Doster JD, Gao Y (2020) Geochemical evaluation of hydrogeologic interaction between the Edwards and Trinity Aquifers based on multiport well assessment in Central Texas. In: Land L, Kromhout C, Byle MJ (Eds) NCKRI Symposium 8: Proceedings of the $16^{\text {th }}$ Multidisciplinary Conference on Sinkholes and the Engineering and Environmental Impacts of Karst, 269-277. https://doi.org/10.5038/9781733375313.1032

Trontelj PC, Douady J, Fišer C, Giber J, Gorički Š, Lefébure T, Sket B, Zakšek V (2009) A molecular test for cryptic diversity in ground water: how large are the ranges of macro-stygobionts? Freshwater Biology 54: 727-744. https://doi.org/10.1111/j.13652427.2007.01877.x

Votteler TH, Gulley RL (2014) The Edwards Aquifer Habitat Conservation Plan: Resolution to over 50 years of water dispute. The Water Report 124: 1-10.

Wang D, Holsinger JR (2001) Systematics of the subterranean amphipod genus Stygobromus (Crangonyctidae) in Western North America, with emphasis on species of the hubbsi group. Amphipacifica 3: 39-147. https://digitalcommons.odu.edu/cgi/viewcontent.cgi?a rticle=1104\&context=biology_etds

Watling L (1989) A classification system for crustacean setae based on the homology concept. In: Felgenhaur BE, Watling S, Thistle AB (Eds) Crustacean issues 6, Functional morphology of feeding and grooming in Crustacea. Rotterdam: AA Balkema, Netherlands, 15-26. https://doi.org/10.1201/9781003079354-2

Wong SS, Yelderman JC (2017) An investigation into the recharge pathways and mechanisms in the northern segment of the Edwards Aquifer, Bell County, Texas (Phase I, Pase II, \& Phase III). Baylor University, Department of Geology final report submitted to Bell County Adaptive Management Coalition. http://staging.cuwcd.org/pdf/Aquifer-Science/ Salado\%20Salamander/CUWCD-Salado-BaylorPhase1-FinalReport.pdf 